ISSN: 1576-0162

DOI: http://dx.doi.org/10.33776/rem.v0i59.5199

\title{
The Opening of Minds towards more Active Government that Steers the Production Structure
}

\author{
ABRIENDO LA MENTE HACIA UN GOBIERNO MÁS ACTIVO QUE PILOTE LA \\ ESTRUCTURA PRODUCTIVA
}

Robert H. Wade

London School of Economics

R.Wade@Ise.ac.uk

Recibido: abril 2021; aceptado: septiembre 2021

\begin{abstract}
Deep society-wide crises tend to produce new economic thinking. 2020 familiarized many millions with trauma and loss. It also intensified the questioning - already started by the North Atlantic Financial Crisis (NAFC) of 2007-12 and by the dramatic rise of China on world technology and military frontiers - of the conservative ideology or world view which has dominated the economics profession and economic statecraft across the capitalist world for the past four decades - dominated as though simple common sense, quietly transforming western societies. This essay discusses the content of emerging thinking about the role of the state, and causes of the changes. But first, more on where we are coming from: from the deeply entrenched conservative ideology and its anti-government "intervention" in the economy.
\end{abstract}

Keywords: Neoliberalism, industrial policy, US, UK.

\section{RESUMEN}

Las crisis sociales profundas tienden a producir un nuevo pensamiento económico. 2020 familiarizó a muchos millones con el trauma y la pérdida. También intensificó el cuestionamiento - ya iniciado por la Crisis Financiera del Atlántico Norte de 2007-12 y por el dramático ascenso de China en la tecnología mundial y las fronteras militares - de la ideología conservadora o visión del mundo que ha dominado la profesión económica y la formulaciōn de políticas económicas en todo el mundo capitalista durante las últimas cuatro décadas (dominado como simple sentido común, transformando silenciosamente las sociedades occidentales). Este ensayo analiza el contenido del pensamiento emergente sobre el papel del estado y las causas de los cambios. Pero antes de ello, algo más sobre de dónde venimos: de una ideología 
conservadora profundamente arraigada y su “intervenciōn” antigubernamental en la economía.

Palabras clave: Neoliberalismo, política industrial, EE.UU., R.U.

JEL Classification / Clasificación JEL: 020, 014, 038, 014. 


\section{INTRODUCTION}

Deep society-wide crises - like depressions, world wars, pandemics - tend to produce new economic thinking. 2020 familiarized many millions with trauma and loss. It also intensified the questioning - already started by the North Atlantic Financial Crisis (NAFC) of 2007-12' and by the dramatic rise of China on world technology and military frontiers - of the conservative ideology or world view which has dominated the economics profession and economic statecraft across the capitalist world for the past four decades - dominated as though simple common sense, quietly transforming western societies. ${ }^{2}$ In particular, the NAFC crystalised just how much the conservative agenda had skewed the functioning of capitalism towards the interests of an elite sliver, undercutting the legitimacy of free market economics and democracy in the eyes of large sections of western populations.

\footnotetext{
${ }^{1}$ North Atlantic Financial Crisis, not the standard "global financial crisis", in keeping with the western habit of identifying major economic crisis with their heartland area, as in "Latin American crisis" or "Asian crisis".

${ }^{2}$ The questioning intensified after the 2008 financial crisis but did not usher in a coherent "conventional wisdom" in place of the conservative world view. This is a conclusion from the study of Cherif and Hasanov (2020), which identifies several "growth narratives" by analysing word frequencies in 4,620 IMF Article IV Country Reports, 1978-2019. "Growth narratives" are stories that simplify and convey complex theories about the causes of economic growth, which themselves are shaped by ideology. The authors identify four main growth narratives, which differ little between Low Income countries, Emerging Market countries, Advanced countries; but change over time: (1) The "Economic Structure" narrative - which talks frequently of "sectors", like services, agriculture, industry, construction - was dominant till the mid-1990s; services was the sector most frequently cited, industry the least. (2) The "Washington Consensus" narrative - which highlights words like "privatization" and "liberalization" took off in the mid-1980s, peaked in the 1990s, and became marginal by the early 2000s. (3) The "Structural Reforms" narrative - including such words as "governance" and "institutions" - continued rising after the decline of the Washington Consensus, and seemed to represent to a large extent a rebranding of it, not a displacement. (4) The "Washington Constellation" narrative - a mishmash of words like "productivity", "business environment", "ease of doing business", "tourism", "infrastructure", "skills", "access to finance" - became dominant in the 2010s, representing a further extension and rebranding (rather than displacement) of the Washington Consensus narrative. "Industrial policy" had a modest frequency - negatively-valanced for developing countries, positively for advanced countries - till the late 1980s, when it disappeared altogether, to stage a modest recovery in the past few years. The bottom line conclusion is that since the 1980s the dominant growth narratives, as seen in these IMF reports, have taken neoliberal beliefs as their center of gravity. This has to qualify the oftenheard claim, "nobody believes the Washington Consensus anymore" and "industrial policy is back".
} 
This essay discusses the content of emerging thinking about the role of the state, and causes of the changes. But first, more on where we are coming from - from the deeply entrenched conservative ideology and its anti-government "intervention" in the economy.

\section{THE CONSERVATIVE IDEOLOGY}

The ideology - often known as neoliberalism - feeds a broader cultural ecosystem based on mistrust of government and the idea of tax-as-theft, as in politicians' everyday talk of "spending taxpayers' money" and the ubiquitous use of the phrase "tax burden". It originated in central Europe during the 1920s and 1930s as a backlash against the dominating role of the state in Russian communism and European fascism, and the aggressive revanchist nationalism they fostered. The neoliberal solution was "less government, more market", which carries the idea that markets are "natural", governments are "artificial" and "intervene" in pre-existing markets, commonly to bad effect. Economic growth and rising prosperity for all depend on the extension of market relations between individuals, businesses and governments, across sectors and across territories. Governments must not chase "the mirage of social justice", in the words of one of the neoliberal founders, Austrian economist Friedrich Hayek. Only markets, not governments, can allocate resources fairly and reward firms and individuals according to their contribution to the economy. Only international markets can connect global capital and business, and squash aggressive nationalism (Slobodian, 2018; Baradaran, 2020).

But neoliberalism remained on the margins of statecraft, while the mainstream became the social democratic ideology of the transformative president, Franklin Delano Roosevelt (FDR), and the New Deal. This constituted the active-government "social protection" end of the pendular swings (or double movement) from "free markets" to "government protection" and back again, which another Austrian economist, Karl Polanyi, identified in the history of capitalism. But it is salutary to recall that two catastrophes - World War One and the Great Depression starting in 1929 - were not sufficient to induce American and allied elites to support a swing towards active government in the 1930s. That needed also the real and present danger of the existing alternatives to "embedded social democracy", namely Soviet communism and German and Italian Fascism. The American and allied elites had to demonstrate their commitment to the more social democratic model, so as not to be identified with these alternatives - but even then, significant fractions of these elites regarded FDR as a grand betrayer of sacred American values of freedom, and still do today.

The quarter century after the Second World War saw relatively fast growth across western Europe and North America, and public policy shaped by strong center-left political parties based on unionised, industrial workers (influential in sanctioning active government, including in supporting the welfare state, even 
when not in power). Economists, in particular neoclassical economists, were marginal in public policy in most of the West from the end of World War Two to the 1970s ("economic growth" hardly featured among the top objectives of governments until the Kennedy administration of the early 1960s).

Then as the quarter century of fast post-war growth sputtered to an end neoclassical economists, especially in the global norm-setting Anglo countries, came riding onto the commanding heights with a simple basic message: growth can be maximized by shrinking government's role in the economy and relying on market competition to produce an efficient distribution of resources and income. Milton Friedman, perhaps the most globally influential economist for several decades after 1970, gave his central message as "governments should get out of the way and let markets and private property work"; and "the social responsibility of business is to maximize its profits (within the law)". He joked that if bureaucrats got hold of the Sahara desert there would soon be a shortage of sand. ${ }^{3}$

The conclusion? As Ronald Reagan said, "the magic of the marketplace" will produce high material prosperity and moral culture. He famously quipped, "The nine most terrifying words in the English language are: 'I'm from the government and I'm here to help'".

The implication is that developed and developing countries alike need a "one size fits all" package of: low taxes, low public spending relative to GDP, low public debt, low regulation, privatization of supply of most private and public goods, and weakening of trade unions so as to make labor markets fully competitive (for the working class, not for graduates). The package helps produce cultural acceptance of purely profit-driven corporate managers and winner-take-most income distribution - whose material benefits will trickle down to the population at large. "A rising tide lifts all boats" became the metaphorical justification.

At the international level, the neoliberal vision sees global prosperity and world peace coming from a world economy integrated through the free flow of,

\footnotetext{
${ }^{3}$ Deepak Lal, director of research at the World Bank in the 1980s, and president of the Mont Pelerin Society in the early 2000s, used to declare to whoever would listen, with the certainty of Revealed Truth, "All governments are predatory." In the US presidential election of 2016 candidate Trump was strongly backed by the Koch brothers and other billionaires in their circle, including Robert Mercer, CEO of Renaissance Technologies, among most profitable hedge funds in the world. Insiders say that Trump was unlikely to have won the Republican nomination or the presidency without Mercer's backing. Mercer's remuneration regularly exceeded \$100 million a year. His philosophy is extreme libertarian, aligned to Ayn Rand's. He is on record as saying that the Civil Rights Act of 1964 was a grave mistake; that climate change is both false and benign; that the Democrats and especially the Clintons were engaged in crimes including murder and sex-trafficking. Jane Mayer (2017) interviewed former high-level employees of Renaissance. One said that Mercer wants to shrink the US government to the size of a pin-head. Another: "Bob thinks the less government the better. He's happy if people don't trust the government. And if the President's a bozo? He's fine with that. He wants it to all fall down." Mercer identified Trump as the person most likely to make the government fall down. Mercer's philosophy aligns with Grover Norquist's. "I don't want to abolish government. I simply want to reduce it to be the size where I can drag it into the bathroom and drown it in the bathtub" (Interview on NPR's Morning Edition, May 25 2001).
} 
first, capital, second, goods and services, and third but with more qualification, labour. Or as a New York Times journalist put it, summarizing the consensus he encountered at the World Economic Forum meeting in Davos, 2002, "A nation that opens its economy and keeps government's role to a minimum invariably experiences more rapid economic growth and rising incomes" (Uchitelle, 2002). The implication is that states should have little more ability to influence these flows than the state governments of the United States. As Martin Wolf said in Why Globalization Works (2004, 4), "It cannot make sense to fragment the world economy more than it already is but rather to make the world economy work as if it were the United States, or at least the European Union." The OECD (Organization for Economic Cooperation and Development) has reliably championed the same "one size fits all" global best practice for achieving higher levels of development: free trade, lower barriers to foreign inward investment, no sectoral industrial policy (2012).

The World Bank has long measured its borrowing countries against the Country Policy and Institutional Assessment formula and used the results to shape lending to low-income countries and its policy dialogue with all its borrowers. The scoring criteria reflect the neoliberal ideology that economic growth is a function of the extension of market relations. And from the early 2000s till 2021 the Bank published an annual flagship report, the Doing Business Report, which ranked countries by the "ease of doing business". Again the scoring criteria reflected the assumption that the lower the taxes, the weaker the regulation, the freer the trade, the higher the ranking. Millions if not billions of dollars were at stake in these rankings, or so it came widely to be believed. China's unhappiness that its low ranking of 78 in 2017 looked likely to be lowered even further to 85 in the 2018 Doing Business Report precipitated a scandal that eventually led the World Bank to discontinue the report in 2021 (WilmerHale, 2021). Many Labour and Social Democratic parties around the world bought into a diluted version of this same neoliberal agenda.

But contrary to common understanding, the neoliberal vision does not simply oppose states and markets, public and private sectors. It does not say that markets must be "liberated" from the state, but that markets must be liberated from democracy. The state must "intervene" to protect property rights over the use of capital from citizens wanting to place limits on the global flow of capital, the state must ensure that trade in goods and services remains free, the state must ensure that labour markets remain free of trade union obstacles.

So states must first cooperate to formulate international rules which ensure the freedom of capital, goods and services (such as through the WTO, the IMF and World Bank), and then each enforce those rules within their own territory, whatever the preferences of their citizens. The coercive function of protecting the property rights of capital and the rules of free trade is one of the primary economic functions of the state (together with macroeconomic stability), for which the state must be "strong" in this particular domain (but not active in others). The EU with its sacred four freedoms of capital, goods, services and 
labour is the real-world qualified triumph of this mindset (Slobodian, 2018; Streek, 2019).

This neoliberal economic moral vision is commonly bolstered by a conservative social moral vision, of a society composed of self-reliant adults who look to themselves and their families to make their way in life, not to the state. The vision contains principles of family organization for bringing up children to be self-reliant adults. The key figure is the "disciplining father", who sets rules for the children, rewards them when they follow the rules, punishes them when they fail to follow the rules; the mother is auxiliary nurturer. George Lakoff (2002) presents extensive evidence from child-rearing books by conservative authors affirming this vision and these principles; and compares with the different vision in child-rearing books by liberal authors (liberal in the American sense).

The public policy prescriptions derived from these economic and the social visions have been invested with high confidence, because derived from (neoclassical) "science". Behind the veil of "science" lay largely implicit philosophical value judgements:

First, "the market" is "natural" and "self-regulating"; the "state" is "artificial" and "self-aggrandizing".

Second, "efficiency" of resource use is the most important criterion for judging policy prescriptions (but efficiency defined in such a way as to build in a presumption that market forces produce efficiency and "government intervention" produces inefficiency, such as deviation of domestic prices from international prices). Hence, more profit-seeking competition in the market raises efficiency, which moves the production structure further towards optimum without government steering.

This paved the way to elevating "just-in-time" sourcing above considerations of "just-in-case" supply chain resilience.

Third, countries should specialize in activities in which they have a "comparative advantage" relative to other activities, and import products of activities in which they do not have comparative advantage. The spirit of this proposition was caught by Michael Boskin, chair of the Council of Economic Advisors in the presidency of George H.W. Bush (1989-93), who allegedly said, "It doesn't make any difference whether a country makes potato chips or computer chips", meaning that a country should specialize in whichever makes most profit. This neglects the fundamental point that economic development is activity-specific, that some activities have a larger beneficial effect on economic development than others, and governments have a legitimate role in accelerating pro-development activities beyond what "the (mostly short-term focused) market" would produce. ${ }^{4}$

\footnotetext{
${ }^{4}$ The classic case in point is the ur-theory of comparative advantage proposed by Englishman (financier, politician) David Ricardo (1817). He concluded that England's comparative advantage was textiles, Portugal's was wine. He did not point out that this gave England the leading technology sector of the day and Portugal a sector with stagnant technology; which would bolster England's
} 
Fourth, the interests of consumers trump those of producers. The implication is that workers should be willing to trade well-paid jobs for low-cost electronics made in China.

Fifth, income is distributed through society according to individuals' ability and hard work (not through institutions like class structure and inheritance rules). The existing market income distribution is mostly fair, and the poor are poor mostly because of their bad choices. ${ }^{5}$ Taxes constrain "freedom", freedom is inversely proportional to one's annual tax liability. Taxes should be low and uniform.

Sixth, there is no difference between income earned by employing labour to produce goods to sell at a profit and then reinvest these profits and form more capital, and income earned by buying a rent-yielding property, or land whose price appreciates without the landlord improving it, or a monopoly and raising the price. There is no difference between earned and unearned income - a distinction fundamental to the classical economists but cancelled by the neoclassicals.

Seventh, "government intervention", including income redistribution (downwards), mostly impairs efficiency and growth. Markets may fail (e.g. monopoly), but "government intervention" fails more often and at higher cost.

Eighth, "place", "location", "nation" are ideas for politics more than for economics. This goes with economists' neglect of the value of community, social connections, common purpose, identification with place and nation. Economics assumes that all people are "anywhere" people as distinct from "somewhere" people, in David Goodhart's distinction (2017).

Led by these taken-for-granted propositions, economists and policymakers systematically downplayed the costs of globalization, as in the above quotes from Uchitelle and Wolf; and largely ignored income distribution.

The labour economist David Autor - among the first to show the damaging local effects of the China shock in the US (the surge in Chinese imports in the early 2000s) - described a "guild orthodoxy" among economists: "the key dictum was that policymakers should be told that trade was good for everyone in all places and all times" (quoted in Hirsh, 2019). Woe betide people who disagreed. The economics Nobel Prize winner, Paul Krugman, dismissed Robert Reich, former Clinton government Labor Secretary who worried about global competition and sought better protection and training for workers, as "an offensive figure, a brilliant coiner of one-liners but not a serious thinker" (in Hirsh, 2019). The "guild orthodoxy" was a diluted variant of the psychological

hegemonic claims and render Portugal even more of an appendage. See Reinert (2003).

5 Senator Mitt Romney, running against Obama in the 2012 presidential election, was asked at a fund-raising event how he planned to "convince everybody you've got to take care of yourself". Romney replied that people who were not convinced they should take care of themselves, who saw themselves as victims, who made themselves dependent on government, comprised $47 \%$ of the electorate. "My job is not to worry about those people. l'll never convince them that they should take personal responsibility for their lives." He implied that almost half the country consisted of parasites (Mayer, 2016, 324). 
mechanism by which "facts" are believed by extremist groups less because they are convinced by the facts than because the beliefs give their sense of community and purpose - in this case, as economists, elite of the social sciences.

Like it or not, the neoliberal conservative world view constitutes a coherent moral vision based on the premise that the "market" is natural and brings freedom, and the "state" is artificial and should be limited to enforcing the market; and the linked premise that fathers must bring up children to be selfreliant adults not dependent on the state. It is more coherent than anything the social democratic or center-left moral vision has produced.

\section{SOCIETAL OUTCOMES}

The dominance of neoliberal economics helped to concretize a neuralgic aversion to the state and dogmatic enthusiasm for tax cuts across the wider conservative movement - because neoliberal economics claimed to base these value judgements on "science". "Fiscal responsibility" came to justify decades of neglect of public services across much of the western world, including local government services like public transport, libraries, youth centers, free school meals, swimming pools, and in some countries more than others, scandalous under-investment in physical infrastructure - notably the US.

Public policy skewed to the interests of the wealthy has sluiced income up to the top of the distribution, especially in the US. Here are three points which illustrate how American society became so bitterly polarized. First, the real income of the richest one percent galloped ahead at the average rate of $2.6 \%$ a year over the 38 years from 1979 to 2017. Taking the middle class as the $20^{\text {th }}$ to the $80^{\text {th }}$ percentile of the income distribution, average income of the US middle class grew at the barely perceptible rate of $1.3 \%$ a year over the same period; and probably grew backwards when one adds in healthcare, education and housing, whose costs have grown significantly faster than the consumer price index.

Second, fifty years ago, in 1970, a typical US CEO of a listed firm earned about 20 times as much as the typical worker. Today, thanks to "globalization" of production and finance, and to the linked radical changes to procedures for setting management pay and bonuses made in the 1990s, the CEO earns about 350 times as much. Meanwhile, investment of corporate profits in people and research has tanked: the share of profits allocated to people and $\mathrm{R} \& \mathrm{D}$ fell from $50 \%$ in the 1980s to $9 \%$ in the 2000s (Peters, 2021).

Third, the US' richest $10 \%$, who own more than $80 \%$ of US stocks, have seen their wealth triple in the past 30 years, while the bottom 50\% had zero gains,

Much of this wealth concentration at the top has been driven by rentier incomes, the kind that troubled the classical economists but barely troubled the neoclassicals. The finance sector and the housing sector, in particular, 
generate vast amounts of rentier income; as do the structures integrating developing countries to the West and facilitating western control of developing country assets (think of how Yeltsin was encouraged by western economists to do a "big bang" privatisation which allowed western investors, and some Russians, to buy up rent-yielding assets).

Yet the steady rise in income and wealth concentration and the squeeze on the middle and lower classes - and the mechanisms behind it - was mostly ignored by economists and most western countries' policymakers. Margaret Thatcher gave the standard rejection in her 1990 slap-down of a Labour member of Parliament expressing worries about income inequality: "The honourable member is saying that he would rather that the poor were poorer, provided the rich were less rich... What a policy!" London School of Economics professor of economics Willem Buiter said in the Financial Times, 2007, "Poverty bothers me. Inequality does not. I just don't care."

The US likes to think of itself as a leader in technology, yet its "social technology" - the role of the state, the creation of an effective welfare state including public health and education systems, public infrastructure, etc. seems hardly to have progressed since the 1960s. The preferences of the wealthy are for private provision, not public. (As the billionaire said to his girlfriend as they descended the steps of his private jet, "Why should my taxes pay for roads and bridges? Afterall, I don't use them.") The touchstone for the present Covid era is an effective, accessible public health system, yet even President Biden seems little prepared to grapple with providing it. Even Obama's health reform was far from what is taken for granted in just about every other high income country. Biden is improving labour protections, but they will still be far below what is expected in most of Europe.

The care-home industry in the US, UK and much of Europe has been given over to private profit-seeking enterprises (including private equity firms), with a built-in incentive to cut costs by lowering standards of care and under-paying staff. The health insurance industry has also been given over to profit-seeking enterprises (also with participation by private equity firms), with a built-in incentive to minimize people with pre-existing conditions and minimize outpayments. The Covid-19 virus found the weak points.

Britain is one of the places where the neoliberal vision has been most fully realized. Privatisation has been taken as an article of religion by successive Conservative governments. So the Thatcher government in the 1980s and start of 1990s privatized the ten regional water utilities in England and Wales. Three quarters of their shares were bought by foreign firms or individuals - including by state-owned foreign firms (apparently foreign states can run commercial enterprises effectively but not the British state). Currently private equity firms with controversial tax-avoidance strategies own a large share of the water 
companies. Britain is one of only five countries in the world where more than $50 \%$ of urban water supply capacity is privately owned. ${ }^{6}$

The Forestry Commission, a government department, has long been Britain's largest landowner, and Conservative governments have long wanted to privatize it. The Cameron government in 2012 announced its privatization plan, greeted with so much protest that it backed off saying it abandoned the idea. Instead, it went ahead in secret. It made a deal with Forest Holidays, in which it owns a $14 \%$ share, to build luxury chalets on long-lease Commission land, paying the Commission an average of $£ 3,000$ a year per chalet and renting the chalets for up to $£ 4,000$ a week, giving Forest Holidays the fourth highest rate of growth of profits for all British companies by 2017. The deal commits the Commission to secrecy; it will ensure that "the media and the public are not aware of new development site selection”. In 2017 a private equity firm acquired $42 \%$ of Forest Holidays, valuing it at an astronomical amount - because, as Forest Holidays' CEO pointed out, the Commission owns millions of hectares of land for it to expand into, with no competitors, no rival bids, no limit to its growth (Jenkins, 2018).

Britain's National Health Service (NHS), free at the point of delivery, is about the most trusted, most cherished institution in the country, but Conservative governments have long wanted to privatize large parts of it. In 2008 the government authorized - without public debate - an American corporate giant, UnitedHealth, to buy a small number of GP surgeries in London, as a foothold. The company's global President, Simon Stephens, had been a close friend and ally of senior Tory politician and later prime minister Boris Johnson at Oxford. Stephens was subsequently appointed chief executive of NHS England, presumably to accelerate covert privatization. Since 2009 some $£ 20$ billion NHS contracts have gone to private firms. In early 2021 the government authorized a subsidiary of the giant US corporation Centene to buy 49 GP surgeries in London with 370,000 patients, again approved with no option for public discussion and with NHS doctors' rival tenders rejected (Foot, 2021). ${ }^{7}$

The other side of Britain's celebration of "the market" is that the central bureaucracy, Whitehall, has been hollowed-out or "infanticised", "consultified", dependent on outsourced work to private consultants. Local government councils too, including Labour Party-controlled ones, have long outsourced much of their activity to private consultants (even simple designs and plans to prettify small stretches of roads), rather than, as in the old days, use Town Hall staff in the architects and building departments drawing on ideas from the local community (Gulliver, 2021). Outsourcing gives "a contract killing" for private consultants and paves the way for national and local government politicians to build "pal-ocracy" networks - eroding state capacity.

\footnotetext{
${ }^{6}$ The others are France, Czech Republic, Malaysia, and Chile.

7 Identifying NHS spending on privates is not straightforward. Difficult judgements have to be made on what is in the numerator of "spending on private sector" and the denominator of "total health spending"; and on separating for-profit and not-for-profit private entities (The Kings Fund, 2019).
} 
The array of "fiscal responsibility" policies win support and finance from the conservative financial and business establishments, whose members hold their noses and ignore smelly aspects of personality, administration, and elimination of non-loyal media, in exchange for property right enforcement, tax cuts for the wealthy, deregulation, trade and production globalization, and opportunities for oligarchic enrichment, under the moral banner of "free markets and fiscal responsibility".

Political leaders and many economists claim that all these measures (the neoliberal agenda) produce big gains for the economy overall. But the losers are rarely comforted by this assurance, and the leaders rely on a second basic tactic to give electoral majorities. To win elections (rigged or unrigged) they have "weaponized" the feelings of helplessness, loneliness and anger among the disadvantaged stoked up by their own "globalization and fiscal responsibility" policies.

The more "populist" of them offer followers a story of good and evil, the sense of belonging to a bigger community of special people seeking the truth, fighting a holy war, uncovering the real conspiracies causing their suffering. They use the visceral vocabulary of "tax is theft", and "government must live within its means, just like the rest of us". They identify Others or Thems who are in the society or trying to get in, who allegedly take power and resources from the real people and silent majority. Former President Obama relates in his A Promised Land that a Republican senator told him, "I hate to say it, but the worse people feel right now, the better it is for us". He may have hated to say it, but he loved to see it.

In the US, the Others, for Republicans, are not just "non-whites", but also Democrats. Just one week before the Biden inauguration, more than $70 \%$ of registered Republicans still said they believed the result was illegitimate, which fed their narrative of betrayal and injustice; and even more said the Biden presidency will do "lasting harm to the US", due to too much "government intervention", pushing it towards "socialism".

The foregoing evidence of societal trends comes mostly from the US and the UK, and the processes are more moderated in parts of Europe. But the basic mechanism at play across much of the West is similar: polarization of employment, income and wealth, has generated political polarization, because the people of a nation see less and less in common, and it becomes more difficult than before to build political coalitions necessary to deliver broadbased prosperity, to deliver "the public interest".

The received conservative truths about fiscal responsibility and limited state took a hammering after the North Atlantic Financial Crisis of 2008, when governments, led by the G20, launched internationally coordinated public spending programmes to offset the collapse of private spending. But then came a ferocious restoration of "fiscal responsibility" across the West, as in German finance minister Wolfgang Schauble's declaration, "austerity is the only cure for the eurozone" (2011). 
The global Covid crisis has forced governments to incur public deficits to limit the collapse of private sector production and employment on a scale relative to GDP not seen since the Second World War. It has turned the spotlight on the decrepit condition of many public infrastructures and services, the minimum pay of "key" public sector workers, and vast income and education disparities. But what happens once the Covid crisis is dealt with? Repeat of 2008 and the hard swing back to deregulation and cuts in public services under the moral banner of "fiscal responsibility"?

\section{OPENING ECONOMISTS' MINDS}

This time we do see momentum for lasting change in mindset, coming from several quarters. For one, the pandemic-induced pressure on governments to run the biggest public deficits since the Second World War has produced a broader questioning of the ur-metaphor that gave the conservative doctrine much of its appeal to the mammalian part of our brain. As expressed by Prime Minister Thatcher in 1983, "the state has no source of money other than the money people earn themselves. If the state wishes to spend more, it can only do so by borrowing your savings or by taxing you more". So the state must manage its finances like a good old-fashioned household and hold spending in line with revenues. But post-NAFC and post-Covid, it has become more widely accepted that governments of countries which maintain control of their currencies can increase spending without raising taxes or borrowing from citizens or other countries, up to the point of unacceptable inflation.

The sense that truths are no longer truths is reinforced by other kinds of evidence accumulating since the NAFC of 2007-12. One key neoliberal claim under question is that profit incentives produce the best outcomes for society. Exhibit A is the private equity (or "leveraged buyout") industry, whose firms use funds provided by pension funds and university endowments and the like to take over and restructure companies, then sell them. They typically cut jobs, pensions, salaries, working conditions, for every last drop of profit. In the past decade, private equity management has led to around 1.3 million job losses in retail bankruptcies and liquidation in the US. Companies that are sold may be hobbled with so much debt as to be unable to survive. Beloved Debenhams is a case in point. Founded in 1778, it became Britain's largest and most multinational department store chain. It was bought by private equity firms in the early 2000s, loaded up with debt, sold, unable to regain profitability with that debt load, and liquidated in 2020 with some 20,000 job losses and 124 store closures. ${ }^{8}$ The threat of being a take-over target has led many companies to cut wages and jobs and raise dividends to avoid the threat.

${ }^{8}$ The immediate cause of Debenhams' collapse was that the owners pursued near-term gains by borrowing not to invest but to pay dividends, creating long-term risks for workers, customers and government that the owners were able to ignore. The backstory is more complicated. Debenhams' 
Evidence has also accumulated against another key neoliberal claim that deregulating industries generates stronger competition, which benefits consumers. The common outcome is that unregulated market competition leads to market consolidation instead. Would-be monopolists squeeze competitors, lobby governments for more deregulation, drive out rivals, resulting in higher corporate concentration, with mixed results for consumers and buckets of rentier income for the monopolists, reinforcing the conservative ideology.

Even bastions of conservative orthodoxy like the IMF have published research which runs against decades of conservative doctrine: fiscal stimulus can be effective; capital controls can be a valuable tool of macroeconomic management; raising public investment by 1 percent of GDP typically raises private investment by much more than 1 percent; and measures to lower income inequality typically bring growth gains greater than the losses caused by the measures to make the redistribution (IMF, 2020; Cherif and Hasanov, 2019; Sandbu, 2020). The IMF's imprimateur makes it easier for national governments to adopt policy norms in favour of more active government.

The opening for new economic thinking made by the NAFC and then by Covid joins up with the older opening made by global warming. The latter has crystallized fundamental issues like "is green growth possible?". Those discussions inevitably raise the question of growth itself, how we measure it, how we should measure it. Ever since the Kennedy government's Commerce Department in 1961 stuck signs on every wall, "What have you done for growth today?" - the first time in history that GDP growth had been taken as the number one (economic) objective of a government - we have rejoiced when growth rises by a percentage point and lamented when it falls by a percentage point (notwithstanding that a few years later John Kennedy's brother Robert liked to say during his 1968 presidential campaign that GDP measures everything "except that which makes life worthwhile") .

Thinking about global warming cannot avoid the distinction between good growth and bad growth. Bad growth includes that component of GDP growth attributable to fossil-fuel subsidies, whose harmful effects (including on global warming) should be subtracted from growth; likewise for expenditures on clearing up the environmental costs "externalized" by private agents polluting rivers and cutting forests. We might even include in bad growth the increment gained by following New York Times journalist Thomas Friedman's tongue-incheek suggestion that - thanks to Trump culture making lying a growth industry

owners were forced to give priority to short-term profits by a heavy debt load imposed by earlier private equity owners. The point applies more widely. Private equity companies buy-out companies, load them with debt, and sell them. The new owners may be obliged to slash costs in order to service the debt, putting the company and employees at risk - extracting value more than creating value. Debenhams was bought by three US private equity firms in 2003, saddled with $\$ 1.2 \mathrm{bn}$ in debt, sold in 2006, and it struggled thereafter to survive with that debt load. As of late 2020, private equity firms are holding between $\$ 2$ and $\$ 2.5$ trillion in "dry powder", awaiting the pandemic's end to buy distressed companies cheaply (Batt and Morgan, 2020). 
- we include the "Iying sector" with its own GDP line, alongside clothing, autos, and financial services (Friedman, 2020).

Still another source of new economic thinking is the spreading worry about the previous non-problem of income inequality. One indicator is the astonishing sales (hardback and e-book) of Thomas Piketty's Capital - a clunky, 600 plus page book about income and wealth inequality. In the first year after publication of the English translation, 2014-2015, about 1.5 million copies globally - though according to a crude Amazon measure, the average Kindle reader stopped on page 12, smashing the previous record for least pages read long held by Steven Hawking's A Brief History of Time, whose average reader stopped on page 16 (Wade, 2014).

Heather Boushey, at the Washington Center for Equitable Growth, explained, "As someone who advises policy-makers, I can tell you there is often this shock: 'The economy is growing. Why aren't people feeling it?' The answer is: because they literally aren't feeling it." (Leonhardt, 2018). A lady at a Remain rally in the north of England (a rally to secure support for Britain remaining in the European Union in the coming referendum of 2016) expressed the same point, more succinctly. The speaker was describing the terrible hit to GDP of Britain's exit. The lady shouted out, "That's your GDP, not ours!" Polling evidence suggests that large swathes of the public think that talk about "the economy" is talk about some entity unrelated to their own lives and employment and well-being, it is something related to elites and people who talk like robots (Wade, 2020).

The evident real-world unhappiness has filtered through to some economists who have begun to focus attention on professional economic ethics. Economics has been an ethics-free zone, much freer than any of the other social sciences, a legacy of neoclassical economics' embrace of late nineteenth century physics as its model. But 2016 saw the publication of The Oxford Handbook of Professional Economic Ethics, edited by George DeMartino and Deirdre McCloskey, which you might think is a slender pocketbook but in fact is even fatter, heavier, and better for co-use in the gym than Piketty's Capital.

The sense that free-market capitalism is not delivering is captured in the trend of responses to questions about satisfaction or dissatisfaction with democracy. The rise in dissatisfaction in the English-speaking democracies since around 2005, led by the US, is striking. And across 77 democracies, with combined population of $2.4 \mathrm{bn}$, the percentage of respondents expressing dissatisfaction with democracy has exceeded $50 \%$ in almost every year since 2008 (Wolf, 2020). We live in a severe global democratic recession, and reversing it should be a high priority for genuine democratic governments and societies around the world. ${ }^{9}$

The evidence of multiplying discontent has given rise to the linked fields of happiness and wellbeing studies. Their central paradox is that rising prosperity

${ }^{9}$ On the long-term democratic recession, globally, see Haggard and Kaufman (2021). 
(measured by GDP) has typically, at least in high income countries, been accompanied by rising unhappiness and mental illness rather than the reverse - for example, a rising proportion of people who say they are not pleased with how their life has progressed. In response, the past two decades have seen an upsurge of attention to societal happiness and how to raise it - for example economist Richard Layard's Happiness: Lessons from a New Science (2005) and psychologist Oliver James's Affluenza (2007). But societal happiness as an objective of economic policy has a much older history. Sociologist Richard Titmuss found to general surprise during the Second World War that the war coincided with improved mental health. He attributed this not only to the cohesive effect of facing a common enemy but also to the impact of universal services which became available during the war, from free school meals to pensions. These created what Titmuss described as "less social disparities", which led to better morale and mental health. Another important contribution came from economist Tibor Scitovsky and The Joyless Economy in 1976, which engaged directly with the paradox that higher incomes do not produce higher happiness, suggesting we should measure the latter directly, because of the wisdom in the saying "we treasure what we measure". The psychologist Martin Seligman popularized the term "well-being" in the early 2000 s and promoted the "positive psychology" movement for teaching happiness in schools.

In short, looking on the bright side, the combination of global warming, soaring income concentration, falling levels of happiness, democracy in recession, and now the Covid pandemic might be enough to keep policymakers' and economists' minds more open than in the wake of the 2008 crash even after Covid is back in the bottle, less zealous to return to "the magic of the market", fiscal responsibility, market discipline, self-reliance and bowling alone as the character of a moral society, more willing to engage with new approaches to previously neglected objectives, more willing to distinguish earned and unearned income in the spirit of the classical economists.

\section{Return OF INDUSTRIAl POLICY}

One of those previously neglected - often emphatically rejected - domains is "industrial policy". ${ }^{10}$ As of the past few years the very words themselves no longer provoke knee-jerk rejection - as in "governments can't pick winners" and "the best industrial policy is none at all ", mind-numbing slogans that over the past four decades echoed around ministries of finance and economics and multilateral organizations (Wade, 1995, 2016, 2017; Cherif et al., 2020).

Here is a case in point. Justin Yifu Lin, a Chinese national with a PhD from the University of Chicago, was chief economist of the World Bank from 2008 to

\footnotetext{
${ }^{10}$ The phrase "industrial policy" is unsatisfactory, not least because the targeted sectors may not be closely related to "industry" in the conventional sense. For simplicity I stick to "industrial policy" here, recognizing its limitations.
} 
2012, the first non-G7 national to hold that position. He wanted to encourage some modest experiments in government support for particular industries ("vertical" or "selective" industrial policy, as distinct from "horizontal" policy to boost the whole private sector). He found little interest on the part of the regional vice presidents, but enough to go ahead with a small pilot project. He saw that the words "industrial policy" must not be used; so the program was christened "the Competitive Partnership Initiative" (no-one could object to any of those words). I spoke to the officer running the program. When I later saw him at lunch with colleagues, I approached and said out loud, "Thank you for the interesting conversation about industrial policy." He leapt to his feet and ushered me aside, telling me sternly not to use those words in connection with his program. When Lin left the Bank, the woman appointed to the position which included the program within its portfolio told her staff that she was from Latin America and "we in Latin America know that industrial policy does not work". She closed the program.

Fast forward to today. The Covid pandemic, which broke in early 2020, has highlighted what was in plain sight but mostly unseen - capitalism can work well when the government exercises its power to guide the market economy, impart "directional thrust", and act as the ultimate absorber of risk for investors and for citizens at large - provided that its policies are not "bought" by the wielders of private economic power.

The Covid pandemic has precipitated more awareness than before that we are facing six or more major crises together:

- Covid;

- precarious employment ("bullshit jobs") and polarized income distribution;

- financial fragility;

- far-reaching disruptions of the "general purpose technologies" released by the "Fourth Industrial Revolution" (including China taking the lead in some key sectors);

- biosphere degradation and climate change;

- loss of trust in government across large swathes of the electorate;

- and growing political tensions between the US, China, and the EU, making cooperation for managing the global commons more difficult (amplified by the internet becoming the "splinternet").

Calls for mega reforms of "fossil-fuel capitalism" and democracy have burst out of the gates like racehorses. The Financial Times editorial of April 32020 said: "Governments will have to accept a more active role in the economy. They must see public services as investments rather than as liabilities, and look for ways to make labour markets more secure. Redistribution will again be on the agenda."

The Financial Times' Ed Luce says: "Whether he meant to or not, Trump has broken the taboo on industrial policy that has existed at least since the Reagan administration" (2020, emphasis added). Why? Because his government gave out some $\$ 14$ billion in federal government subsidies to the big pharma 
companies, like Pfizer, Moderna and others to produce vaccine as fast as possible. It eliminated most private sector risk; this enabled corporations to throw everything at finding a solution, in the spirit of "mission economics". Luce goes on to say that Biden "wants to revive the kind of industrial policy on which Eisenhower embarked after the Soviets launched the Sputnik satellite in the late 1950s." Rana Faroohar adds: "the publicly-funded backing of big ideas (railroads, the internet, etc.), that are then commercialized by the private sector, is pretty much the only thing that ever creates sustainably shared growth at scale" (2020). Mariana Mazzucato makes basically the same argument in The Entrepreneurial State (2013).

Competition from China and its intense top-down industrial policy adds to the push elsewhere. The West has come to realize that China is no longer an "emerging" capitalist economy. It is the world's second-largest economy, organized with a party-state directing, penetrating the economy to a much greater extent than in the West, and competing head-to-head with the US and the EU for global influence. Its size, competitive success and its "otherness" has propelled new acceptance in the West of the role of the state in guiding investments in emerging technologies like artificial intelligence, quantum computing and clean energy, to better counter competition from Chinese stateguided firms. In particular, the Covid crisis has forced the West - states and firms - to realize that it has become too dependent on China as a manufacturing center, and to think more strategically about the location of production chains, with more weight to "resilience" than when efficiency and "just-in-time" was all.

For example, China is already the world's largest car market, accounting for a third of global sales. Worried about pollution problems and keen to achieve leadership in technologies of the future, the government has lavished subsidies on the electric car industry, which now produces more big battery packs for e-cars than the rest of the world combined and dominates the world's production of electric motors. In 2017 the government announced that it was phasing out fossil fuels for cars by a then-unspecified date. Two weeks later the CEO of the US's General Motors flew to Shanghai, where she declared that consumers, not governments, should decide when to stop buying gasoline- and diesel-powered cars. The contrast with China's top-down policy is sharp. The government has set high targets and offered to help Chinese companies meet them (Bradsher, 2021).

The Covid pandemic and the fight for protective equipment and vaccines has reinforced the emerging political divergence between the world's key trading blocs - the US, China and the EU. That divergence in turn prompts business and governments to re-regionalise supply chains of critical goods and services - which gives further impetus to industrial policy as governments strategize about what industries to support.

Semiconductors are an important case in point. Most US and European companies rely on chips made in Asia. US and European governments are actively considering how to bring some semiconductor manufacturing back to western sites - and more broadly, how to create high-tech challengers to 
foreign rivals - without allowing state support to produce flabby also-rans (Financial Times, 2021).

To illustrate "varieties of industrial policy", I now give short accounts of how the US state has conducted sub-rosa industrial policy behind a neoliberal screen, and how the British state recently has mounted what it calls "industrial strategy", apparently stepping away from neoliberal norms while not actually doing so.

\subsection{US DE FACTO, SUB-ROSA INDUSTRIAL POLICY}

As we saw, the Reagan presidency launched neoliberalism into the mainstream of US statecraft and then into almost-global statecraft. It became widely believed that the US had no industrial policy; as sociologist Michael Mann concluded, "there is no serious American industrial policy; this is left to the post-war powerhouses of the US economy, the large corporations" (1997, 484). The US government both directly and indirectly through organizations like the World Bank has long urged the rest of the world to follow economics Nobel laureate Gary Becker's dictum, "the best industrial policy is none at all".

In fact, the US has long had a "disguised developmental state", though more accurately, a "disguised and fragmented developmental state" (B lock, 2008; Wade, 2017; Weiss, 2005). ${ }^{11}$ Henry Etzkowitz and colleagues find: "Below the ideological surface a powerful 'jerry built' substrate has emerged of federal, state and local government innovation support programs each filling gaps in the other" $(2008,685)$. At the top, there is no "pilot agency" equivalent to Japan's Ministry of Science and Technology (MITI) and its Taiwanese and South Korean counterparts. Powerful agencies like ARPA (Advanced Research Projects Agency), NASA, and National Institutes of Health - only loosely coordinated - sponsor a lot of "mission"-type R\&D. Other agencies - including the National Institute of Standards and Technology, the Manufacturing Extension Partnerships (MEPs), and the Small Business Administration, operating at national, state and city levels - do more by way of nudging firms to upgrade and seek new markets (very different from "making winners").

Whether for national projects or lower down, much of the public work is to build and sustain networks among competing firms, to induce them to cooperate on certain projects. The emphasis on networks follows from the radical change in production structure with the decline of vertically integrated

11 The Trump government gave a real-world demonstration of how quickly "state capacity" can be dismantled. Even before he took office in 2016 he declared hostility to "experts" and science (as did senior figures in Boris Johnson's government in Britain). In power the government eviscerated many important agencies which together constituted the US's disguised developmental state. It left the key Office of Science and Technology Policy without leadership for nearly two years (the head of the office is normally also the chief scientific adviser) and cut its staff to a fraction of what it was during the Obama government. It slashed agencies like the Centers for Disease Control and the Environmental Protection Agency. On the campaign trail in 2020 Trump warned his audience that "Biden will listen to the scientists" (Tett, 2021). 
production in giant corporations and the rise of organizational decentralization and spatial decentralization, making production complexes of smaller-scale suppliers and middlemen in organizational networks at home and abroad. Such networks do arise spontaneously. But evidence suggests that government support tends substantially to prolong their life and enables the public agencies to steer their direction in line with public purposes. To understand this type of industrial policy, we need to understand network dynamics and network failure, as distinct from the standard binary of market failure and government failure (Schrank and Whitford, 2009). ${ }^{12}$

\subsection{The United Kingdom and industrial policy: Receding of neOliberalism?}

In the UK the crisis of 2008, followed by the 2016 referendum to leave the European Union by 2020, created opportunities for the UK state to adopt new policy norms, and apparently it did. It has a long history as a "regulatory" state, with little role in steering changes in economic structure (little role in "development" as distinct from "growth"). To the extent it did "vertical" or "sectoral" industrial policy, it acted mostly to save employment-intensive firms, while it sat on its hands as crown-jewels of British industry were sold to foreign buyers or split up and the parts sold separately. ${ }^{13}$ In contrast, the new Prime Minister, Theresa May, in 2016, oversaw the establishment of the Department for Business, Energy and Industrial Strategy (BEIS), and publication of a landmark White Paper on Industrial Strategy in 2017 (BEIS, 2017).

The usual interpretation of a move towards industrial policy or strategy (when made by any government anywhere) is that it represents a "receding" of neoliberal influence over economic statecraft, an embrace of a more active directive role of the state in shaping the structure of the economy than neoliberalism could endorse. But looked at more closely, the UK case represents not a receding but "reseeding" of neoliberalism in new institutions, as Craig Berry argues (2020). The two words sound the same but have opposite meanings.

12 For a detailed study of German industrial policy via the huge development bank, KfW, see Naqvi et al. (2018).

13 A current case concerns Arm, one of precious few, globally relevant UK-based technology firms, a computer chip designer and one of the world's most valuable intellectual property companies. It is estimated that between smart-phones, connected cars and other electronics there are an average of 20 Arm-designed chips for every person on the planet. The Conservative government cheered in 2016 when the company was bought by Japan's Softbank, with guarantees to expand employment in its Cambridge headquarters. In 2020 Nvidia, the US company that has overtaken Intel to become the world's most valuable chip maker, announced it wants to buy Arm, which would likely mean Arm's skills migrating to America and Arm's business model disrupted by being tied in to making designs for Nvidia, strengthening Nvidia's market position and loosing other customers. Arm's CEO said the deal would be "an absolute disaster for Cambridge, the UK and Europe". But the Conservative government seems mostly unconcerned at the prospect of sale to Nvidia ("the market should determine Arm's fate"), not least because of its need to win favour in Washington. In January 2021 the UK Competition and Markets Authority announced a formal investigation later in the year (Thornhill, 2021). 
The May government's move retains the assumption that the state's main role is to sustain the neoliberal growth model - based on the neoliberal premise that the private sector of Milton Friedman's profit-maximizing firms (rentier or not) should be the place which determines how wealth is produced and distributed. The move remains in neoliberal grooves in two ways. First, the powerhouse Treasury, center of the neoliberal and finance-oriented worldview in the UK executive branch, presides over BEIS and the industrial strategy. Second, the content of the industrial strategy is determined largely by representatives of private economic actors, with civil service counterparts operating mostly in service mode (a reflex of the "infantilization" of the civil service mentioned earlier). If the East Asian developmental states operated on the principle of "embedded autonomy" (state agencies operated in close coordination with private entities but retained autonomy), the new British industrial strategy operates on the principle of "embedded non-autonomy".

One of the main instruments of UK industrial strategy is the "sector deal", a loosely structured partnership between government and private bodies in a given industry (e.g. autos, food and drink, life sciences, creative industries). Typically, the sector deal entails a commitment of firms to invest in new products, locate in certain places, and do $R \& D$, in return for subsidies, tax relief, looser planning regulations, and infrastructure investment.

Note several points. First, sector deals are institutionalized to give powerful incumbent firms the primary role in shaping industrial policy measures - so they marginalize innovative and disruptive firms. The first criterion new sector deals must reach is having an "identifiable leader who can bring together an appropriately broad representation of the sector" (BEIS 2017, 208) - such as the chief executive of engineering giant GKN for the automobile sector deal, and Facebook's vice-president for Europe for the creative industries sector deal.

Second, the sector deals represent a one-way outsourcing of innovation risks by capitalists to the public sector.

Third, as Craig Berry remarks: "There is of course no suggestion that the public purse might benefit (...) from any profits which derive from an activity supported by sector deal, or that the beneficiaries might be held accountable for how they use public funds" (Berry, 2020, 612).14

Finally, note that the UK had the lowest rate of productivity growth in the G7 leading high-income countries apart from Italy in 2010-2019; and the lowest average investment in $R \& D$ apart from Italy. But the rentier-oriented finance and property sectors have flourished.

\footnotetext{
14 The Obama government's space program illustrates potential advantages of putting private firms in the driving seat, in some cases. It turned NASA into a major funder of entrepreneurial private firms, like SpaceX and Blue Origin. Instead of the usual method of the Pentagon and NASA dictating terms to contractors, the private firms put up proposals for funding. It was private firms, inspired by the iPhone, which led the development of small re-usable rockets and satellites as small as loaves of bread, while the public agencies were locked into bigger and bigger. This is an example of government "followership" of the market, as distinct from leadership.
} 


\section{Conclusions}

This essay has described clear signs of a new politics, a new economic statecraft coalescing, when the conventional neoliberal wisdom about deficits, inflation, "government intervention" and the "magic of the market" has fallen apart in the minds of many who formerly believed it. The essay suggests several causes.

One is that professional economists are pushing the discipline in new directions at a speed not seen before. ${ }^{15}$

Second, the Covid crisis and Great Recession, coming on top of the NAFC and Great Recession, has forced through a much more active role of government in the economy than neoliberalism can sanction, including in the lightning speed of vaccine development. And governments have learnt enough about the polarizing and impoverishing effects of "austerity" to be cautious in reimposing austerity post-Covid when inflation and interest rates are very low, as they did post-NAFC. The US case shows how much the political parameters have changed: the US Congress approved, but with difficulty, a \$1 trillion stimulus package after the financial crisis of 2008, but had no problem approving a \$2.2 trillion rescue in March 2020 and another $\$ 900$ billion in December 2020; and Biden's government is pushing for another $\$ 1.9$ trillion package.

Third, a whole wave of life-transforming technology innovations is under way, including in energy (geothermal, hydrogen, nuclear fusion in compact reactors, thorium nuclear, biomethane), driverless vehicles, long-range fastcharging electric cars, artificial intelligence and machine learning, lab-grown meat, and more. Governments have a responsibility to oversee these profound changes, including by exercises in foresight across the national and global economies, and by providing social protection to mitigate the coming massive disruptions.

Fourth is the rapid rise of China as competitor in many high tech sectors previously the preserve of the West, including nanotech, industrial biotech, new materials and renewable energy. The Chinese government has no hesitation in using vigorous industrial policy to raise China's $R \& D$ and market share, including through its control over the allocation of capital and state-owned enterprises; and it is starting (as of 2021) to crack down on rentier incomes and stop the economic power of billionaires from buying political power.

Fifth is the growing political divergence between the world's main trading blocs - US, China, and EU - and the need to rethink supply chains of critical goods; which again needs the active strategizing of the state guided by exercises in foresight across the whole national and world economy.

${ }^{15}$ Martin Sandbu of The Financial Times says: "In terms of practical thinking, the policy advice from places such as the IMF has changed almost beyond recognition [since around 2017] from the old 'Washington Consensus' of fiscal conservatism and market self-regulation". In terms of macroeconomics, models are being developed with multiple equilibria, and "taking multiple equilibria seriously makes for fundamental change in how economics is applied to policymaking" (2021). 
Six, the combination of serious crises in climate, inequality of income and wealth, and democracy also wins support in parts of business and in the public at large for a more active role of the state, including in industrial policy.

But the return of a more active state cannot be taken for granted. Post Covid, we will see strong tension between those demanding - in the name of freedom and prosperity - "reglobalisation", "fiscal responsibility", weakening of labour power, and a big retrenchment in public spending (forgetting that "fiscal austerity" was a main reason why a resilient recovery failed to emerge after 2010), and those pressing to rethink national objectives, the responsibility of business, and the role of government in relation to business and the social contract and to the environment. Those seeking to move society in the direction of a more active state pursuing public purposes - without its activism being captured by private oligarchs - have their work cut out against the force of dominant class interest, focused on ensuring that the drive for "status" dominates the drive for "fairness".

\section{REFERENCES}

Batt, R. and Morgan, J. (2020). Private Equity and Public Problems in a Financialized World: an Interview with Rosemary Batt. Real-world Economics Review, 94 .

Baradaran, M. (2020). The Neoliberal Looting of America. New York Times (International), July 6.

BEIS (Business, Energy and Industrial Strategy Department), (2017). Industrial strategy: building a Britain fit for the future.

Berry, C. (2020). From Receding to Reseeding: Industrial Policy, Governance Strategies and Neoliberal Resilience in Post-crisis Britain. New Political Economy, 25 (4), 607-625.

Block, F. (2008). Swimming Against the Current: the Rise of a Developmental State in the United States. Politics \& Society, 36 (2), 169-206.

Bradsher, K. 2021 China in the Lead as Cars Go Electric. New York Times (International), February 2.

Cherif, R. and Hasanov, F. (2019). The Return of the Policy That Shall Not Be Named: Principles of Industrial Policy. IMF Working Paper, 19/74.

Cherif, R., Engher, M. and Hasanov, F. (2020). Crouching Beliefs, Hidden Biases: the Rise and Fall of Growth Narratives, IMF Working Papers, November 8.

DeMartino, G. and McCloskey, D. (eds.) (2016). The Oxford handbook of Professional Economics Ethics. Oxford University Press.

Etzkowitz, H. et al. (2008). Pathways to the Entrepreneurial University: Towards a Global Convergence. Science and Public Policy, 35 (9), 681-95.

Faroohar, R. (2020). Covid and the Rebirth of US Industrial Policy, Swampnotes. Financial Times, December 18.

Financial Times, (2021). The Risks from a Dash to Chip Nationalism, editorial. February 16. 
Foot, T. (2021). The Great GP Surgery Takeover. Camden New Journal, February 18.

Friedman, T. (2020). Only Truth Can Save America. New York Times (International), November 12.

Goodhart D. (2017). The Road to Somewhere: The New Tribes Shaping British Politics. Penguin.

Grabel, I. (2017). When Things Don't Fall Apart: Global Financial Governance and Development Finance in an Age of Productive Incoherence. MIT Press.

Grove, A. (2010). How American Can Create Jobs. Business Week, July 1.

Gulliver, J. (2021). A Contract Killing for Private Consultants. Camden New Journal, January 21.

Haggard, S. and Kaufman, R. (2021). Backsliding: Democratic Regress in the Contemporary World. Cambridge University Press.

Hirsh, M. (2019). Economists on the Run. Foreign Policy, October 22 https:// foreignpolicy.com/2019/10/22/economists-globalization-trade-paul-krugman-china/

IMF (2020). World Economic Outlook, Washington DC.

James, O. (2007). Affluenza. Vermillion.

Jenkins, S. (2018). Will we Stand by and Watch the Privatisation of Our Forests? The Guardian, 27 April.

Lakoff, G. (2002). Moral Politics: How Liberals and Conservatives Think. University of Chicago.

Layard, R. (2005). Happiness: Lessons from a New Scienc. Allen Lane.

Leonhardt, D. (2018). We're Measuring the Economy all Wrong. New York Times (International), 15-16 September.

Luce, E. (2020). Covid and the Rebirth of US Industrial Policy, Swampnotes. Financial Times, December 18.

Mann, M. (1997). Has Globalization Ended the Rise and Rise of the Nation State. Review of International Political Economy, 4 (3), 472-96.

Mayer, J. (2016). Dark Money: How a Secretive Group of Billionaires Is Trying to Buy Political Control in the US, Scribe.

Mayer, J. (2017). The Reclusive Hedge Fund Tycoon Behind the Presidency, The New Yorker, March 17.

Mazzucato, M. (2013). The Entrepreneurial State: Debunking Public and Private Sector Myths. Anthem Press.

Naqvi, N., Henow, V. and Chang, H-J. (2018). Kicking Away the Financial Ladder? German development banking Under Economic Globalisation. Review of International Political Economy, 25 (5), 672-98.

O'Connor, S. (2021). The US and the UK Chart Different Courses on Worker Rights, Financial Times February 2.

OECD (2012). Reducing the Thickness of Borders to Promote Trade and Participation in Global Value Chains.

Peters, T. (2021). McKinsey's Work on Opioid Sales Represents a New Low. Financial Times, February 16. 
Pistor, K. (2019). The Code of Capital: How Law Creates Wealth and Inequality. Princeton University Press.

Reinert, E. (2003). Austrian Economics and the Other Canon: The Austrians Between the Activistic-Idealistic and the Passivistic-Materialistic Traditions of Economics, in Backhaus, J. (ed.), Evolutionary Economic Thought, E. Elgar. Sandbu, M. (2020). Dawn Breaks on a New Era of Thinking, Financial Times, 12 October.

Sandbu, M. (2021). The Revolutions Underway in Macroeconomics. Financial Times, January 28.

Schauble, W., (2011). Austerity is the Only Cure for the Eurozone. Financial Times, September 5.

Sharma, R. (2021). Dear Mr Biden, Debt and Deficits Still Matter. Financial Times 21 January.

Slobodian, Q. (2018). Globalists: The End of Empire and the Birth of Neoliberalism. Harvard University Press.

Streek, W. (2019). Fighting the State. Development and Change 50 (3), 836-847. Tett, G. (2021). Two Cheers for Biden's Science Revival. Financial Times, January 22.

The Kings Fund (2019). Is the NHS Being Privatised? Newsletter, October 17. Thornhill, J. (2020). Arm's Destiny is Vital for Britain's Future. Financial Times, August 31.

Wade, R. H. (1995). Resolving the State-Market Dilemma in East Asia, in Chang, H-J. and Rowthorn, R. (eds.), The Role of the State in Economic Change, Clarendon Press.

Wade, R. H. (2014). The Piketty Phenomenon and the Future of Inequality. Real-world Economics Review, 69, Special issue on Piketty's Capital.

Wade, R. H. (2016). Industrial Policy in Response to the Middle-Income Trap and the Third Wave of the Digital Revolution. Global Policy, November, http://onlinelibrary.wiley.com/doi/10.1111/gpol.2016.7.issue-4/issuetoc

Wade, R. H. (2017). The America Paradox: Ideology of Free Markets and Hidden Practice of Directional Thrust. Cambridge J. of Economics, 41 (3), May.

Wade, R.H. (2020). Globalisation, Inequality and Poverty: Power and Evidence in 'Best Practice' Economic Policy, Chapter 12, J. Ravenhill (ed), Global Political Economy, $6^{\text {th }}$ edition, OUP.

Weiss, L. (2005). Global governance, National Strategies: How Industrial States Make Room to Move under the WTO. Review of International Political Economy, $12(5), 723-49$.

WilmerHale, (2021), Investigation of Data Irregularities in Doing Business 2018 and Doing Business 2020, September 15.

Machen, R., Jones, M., Varghese, G. and Stark, E. (2021). Investigation of Data Irregularities in Doing Business 2018 and Doing Business 2020.World Bank.

Wolf, M. (2004). Why Globalization Works, Yale.

Wolf, M. (2020). Democracy in a Time of Division. Financial Times, November 11. 
